\title{
Small Molecule Targeting of PAI-1 Function: A New Therapeutic Approach for Treatment of Vascular Stenosis
}

\author{
Tessa M. Simone, Jaclyn Archambeault and Paul J. Higgins* \\ Center for Cell Biology \& Cancer Research, Albany Medical College, Albany, New York 12208, USA
}

Plasminogen activator inhibitor-1 (PAI-1; SERPINE1) is a clade E1 member of the serine protease inhibitor (SERPIN) superfamily and the major physiologic inhibitor of the urokinase ( $\mathrm{UPA}$ ) and tissuetype (tPA) plasminogen activators. Elevated PAI-1 expression is a significant causative factor in vascular disease and a major contributor to the pathophysiology of diabetes, metabolic syndrome, stroke, atherosclerosis and restenosis, particularly in the setting of increased vessel TGF- $\beta 1$ [1-3].

PAI-1 is unique relative to other SERPINs existing in the structurally and functionally distinct active, latent and cleaved conformations $[4,5]$. PAI-1 is initially synthesized in an active state, capable of interacting with its proteinase targets, but is unstable (half-life of 2 hours at $37^{\circ}$ $\mathrm{C}, \mathrm{pH}$ 7.4) and converts spontaneously into a latent form [6]. Latency requires insertion of the $\mathrm{N}$-terminus of the PAI-1 reactive center loop into $\beta$-sheet $\mathrm{A}$ forming a new $\beta$-strand ( $\mathrm{s} 4 \mathrm{~A}$ ) which creates an unusual loop structure and conformational change in the reactive center, ultimately preventing interaction with proteinases [7-9]. Alternatively, PAI-1 can be proteolytically-cleaved at the sissile P1-P1' bond causing the $\mathrm{N}$-terminal end of the reactive center loop to insert into $\beta$-sheet $\mathrm{A}$, while the $\mathrm{C}$-terminus of the reactive site loop forms strand $\mathrm{s} 1 \mathrm{C}$ in $\beta$-sheet C. These structural rearrangments produce a $70 \AA$ separation of the P1 and P1' residues, thereby, preventing PAI-1 from complexing with the target proteinase due to spatial distortion, ultimately allowing for increased plasmin activation [10-12]. While neither cleaved nor latent PAI-1 forms complexes with their target proteases, all three conformations bind the low-density lipoprotein receptor-related protein-1 (LRP1) and initiate Jak/Stat signaling [13].

Elevated PAI-1 mRNA and protein expression are evident in the carotid vascular wall adjacent to thrombi induced by implantation of indwelling polyethylene tubing [14]. Furthermore, adenoviral delivery of PAI-1 potentiated neointima formation after catheter-induced injury while copper-stimulated neointima formation was reduced in PAI-1-null mice $[15,16]$. In a mouse model of carotid artery ligation, PAI-1 protein levels are elevated in neointimal lesions 14-days after restriction. Regions expressing PAI-1 also express smooth muscle cell $\alpha$-actin (Figure 1A,C), suggesting that PAI-1 is associated with smooth muscle cells (VSMCs). PAI-1 involvement in the pathological response to healing is reflected in its expression in the developing neointima in the ligated artery, but not the contralateral control vessel (Figure $1 \mathrm{~B}, \mathrm{D})$, as well as in balloon-injured carotid arteries (Figure 1E). These findings implicate PAI-1 as a significant factor in the development of restenosis and provided the impetus for development of low-molecular weight PAI-1 antagonists. Tiplaxtinin (PAI-039), the most well studied small molecule PAI-1 inhibitor, attenuates asthmatic episodes, obesity, diabetes, cancer cell motility and angiogenesis [17-24]. The mechanism by which Tiplaxtinin antagonizes the anti-fibrinolytic activity of PAI1 appears to involve inhibition of complex formation between PAI-1 and its target protease with promotion of PAI-1 cleavage [25,26]. This has translational implications as PAI- 1 deficiency in various cell types promotes plasmin-dependent apoptosis [27-31]. A decrease in PAI1 antiproteolytic activity, through functional blockade or proteolytic

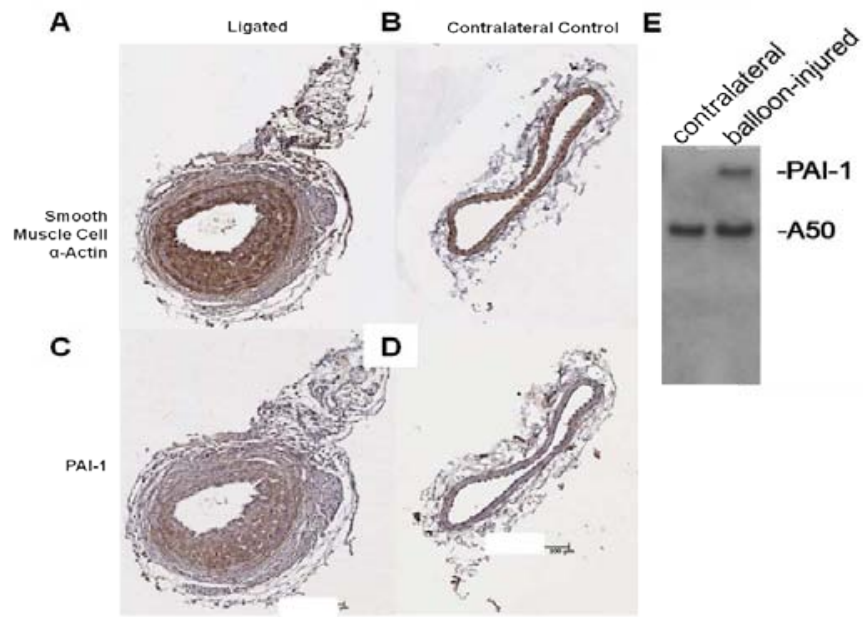

Figure 1: PAl-1 expression is upregulated within vascular smooth muscle cells of neointimal lesions. A-D.) Paraffin sections $(5 \mu \mathrm{m})$ of ligated (A\&C) and contralateral control (B\&D) mouse, common, carotid arteries were subjected to PAI-1 (C\&D) or smooth muscle cell $\alpha$-actin (A\&B) staining. Images taken with a 10x objective. E.) Rats were subjected to balloon-catheter endothelial denudation injury of the left common carotid artery. One week later, RNA was extracted from the injured carotids as well as the contralateral control arteries. Northern blot analysis of mRNA levels using 32P-labeled cDNA probes to PAI-1 and A50 (loading control).

cleavage, may subsequently increase VSMC apoptosis due to plasmin generation. One mechanism suggests that PAI-1 might contribute to neointimal growth by facilitating VSMC survival. Recent findings indicate that Tiplaxtinin induces VSMC apoptosis in a dose-dependent manner and this response was attenuated by the addition of TGF- $\beta 1$. However, with the exception that PAI-1 binds and prevents the cleavage and activation of caspase-3, the role of PAI-1 in preventing VSMC apoptosis remains unexplored [31]. One attractive possibility is that PAI-1 might promote cell survival through the PI3K/Akt signaling axis and both PAI- 1 and TGF- $\beta 1$ stimulate AKT phosphorylation. Since PAI-1 is a highly upregulated gene in the TGF- $\beta 1$ response set, TGF- $\beta 1$ may activate Akt through PAI- 1 or, at least, induce PAI- 1 expression through an Akt-dependent pathway. Given the ubiquitous role PAI-1 plays in the etiology and progression of several chronic and acute fibrotic disorders, the therapeutic efficacy of small molecule PAI-

*Corresponding author: Dr. Paul J. Higgins, Center for Cell Biology \& Cancer Research, Albany Medical College, 47 New Scotland Avenue, Albany, New York 12208, USA, Tel: 518-262-5168; FAX: 518-262-5669; E-mail: higginp@mail.amc.edu

Received July 04, 2013; Accepted July 05, 2013; Published July 08, 2013

Citation: Simone TM, Archambeault J, Higgins PJ (2013) Small Molecule Targeting of PAl-1 Function: A New Therapeutic Approach for Treatment of Vascular Stenosis. J Mol Genet Med 7: 059. doi:10.4172/1747-0862.1000059

Copyright: (C) 2013 Simone TM, et al. This is an open-access article distributed under the terms of the Creative Commons Attribution License, which permits unrestricted use, distribution, and reproduction in any medium, provided the original author and source are credited 
Citation: Simone TM, Archambeault J, Higgins PJ (2013) Small Molecule Targeting of PAI-1 Function: A New Therapeutic Approach for Treatment of Vascular Stenosis. J Mol Genet Med 7: 059. doi:10.4172/1747-0862.1000059

1 inhibitors, such as Tiplaxtinin, may have translational adapatability beyond the scope of vascular disease.

\section{Acknowledgements}

Supported by NIH grant GM057242.

\section{References}

1. Wu K, Urano T, Ihara H, Takada Y, Fujie M, et al. (1995) The cleavage and inactivation of plasminogen activator inhibitor type 1 by neutrophil elastase: the evaluation of its physiologic relevance in fibrinolysis. Blood 86: 1056-1061.

2. Otsuka G, Agah R, Frutkin AD, Wight TN, Dichek DA (2006) Transforming growth factor $\beta 1$ induces neointima formation through plasminogen activator inhibitor-1-dependent pathways. Arterioscler Thromb Vasc Biol 26: 737-743.

3. Otsuka G, Stempien-Otero A, Frutkin AD, Dichek DA (2007) Mechanisms of TGF-beta1-induced intimal growth: plasminogen-independent activities of plasminogen activator inhibitor-1 and heterogeneous origin of intimal cells. Circ Res 100: 1300-1307.

4. Declerck PJ, De Mol M, Vaughan DE, Collen D (1992) Identification of a conformationally distinct form of plasminogen activator inhibitor-1, acting as a noninhibitory substrate for tissue-type plasminogen activator. J Biol Chem 267: 11693-11696.

5. Urano T, Strandberg L, Johansson LB, Ny T (1992) A substrate-like form of plasminogen-activator-inhibitor type 1. Conversions between different forms by sodium dodecyl sulphate. Eur J Biochem 209: 985-992.

6. Dellas C, Loskutoff DJ (2005) Historical analysis of PAl-1 from its discovery to its potential role in cell motility and disease. Thromb Haemost 93: 631-640.

7. Mottonen J, Strand A, Symersky J, Sweet RM, Danley DE, et al. (1992) Structural basis of latency in plasminogen activator inhibitor-1. Nature 355 : 270-273.

8. Levin EG, Santell L (1987) Conversion of the active to latent plasminogen activator inhibitor from human endothelial cells. Blood 70: 1090-1098.

9. Lindahl TL, Sigurdardottir O, Wiman B (1989) Stability of plasminogen activator inhibitor 1 (PAl-1). Thromb Haemost 62: 748-751.

10. Patston PA, Gettins P, Beechem J, Schapira M (1991) Mechanism of serpin action: evidence that $\mathrm{C} 1$ inhibitor functions as a suicide substrate. Biochemistry 30: 8876-8882.

11. Gils A, Declerck PJ (1997) Proteinase specificity and functional diversity in point mutants of plasminogen activator inhibitor 1. J Biol Chem 272: 12662 12666

12. Aertgeerts K, De Bondt HL, De Ranter CJ, Declerck PJ (1995) Mechanisms contributing to the conformational and functional flexibility of plasminogen activator inhibitor-1. Nat Struct Biol 2: 891-897.

13. Degryse B, Neels JG, Czekay RP, Aertgeerts K, Kamikubo Y, et al. (2004) The low density lipoprotein receptor-related protein is a motogenic receptor for plasminogen activator inhibitor-1. J Biol Chem 279: 22595-22604.

14. Sawa H, Sobel BE, Fujii S (1993) Potentiation by hypercholesterolemia of the induction of aortic intramural synthesis of plasminogen activator inhibitor type 1 by endothelial injury. Circ Res 73: 671-680.

15. Ploplis VA, Cornelissen I, Sandoval-Cooper MJ, Weeks L, Noria FA, et al. (2001) Remodeling of the vessel wall after copper-induced injury is highly attenuated in mice with a total deficiency of plasminogen activator inhibitor-1. Am J Pathol 158: 107-117.

16. DeYoung MB, Tom C, Dichek DA (2001) Plasminogen activator inhibitor type 1 increases neointima formation in balloon-injured rat carotid arteries. Circulation 104: 1972-1971.

17. Lee SH, Eren M, Vaughan DE, Schleimer RP, Cho SH (2012) A plasminogen activator inhibitor-1 inhibitor reduces airway remodeling in a murine model of chronic asthma. Am J Respir Cell Mol Biol 46: 842-846.
18. Krause MP, Moradi J, Nissar AA, Riddell MC, Hawke TJ (2011) Inhibition of plasminogen activator inhibitor-1 restores skeletal muscle regeneration in untreated type 1 diabetic mice. Diabetes 60: 1964-1972.

19. Lijnen HR, Alessi MC, Frederix L, Collen D, Juhan-Vague I (2006) Tiplaxtinin impairs nutritionally induced obesity in mice. Thromb Haemost 96: 731-737.

20. Schalkwijk CG, Stehouwer CD (2006) PAI-1 inhibition in obesity and the metabolic syndrome: a promising therapeutic strategy. Thromb Haemost 96 698-699.

21. Leik CE, Su EJ, Nambi P Crandall DL, Lawrence DA (2006) Effect of pharmacologic plasminogen activator inhibitor-1 inhibition on cell motility and tumor angiogenesis. J Thromb Haemost 4: 2710-2715.

22. Crandall DL, Quinet EM, El Ayachi S, Hreha AL, Leik CE, et al. (2006) Modulation of adipose tissue development by pharmacological inhibition of PAl-1. Arterioscler Thromb Vasc Biol 26: 2209-2215.

23. Lijnen HR, Alessi MC, Van Hoef B, Collen D, Juhan-Vague I (2005) On the role of plasminogen activator inhibitor-1 in adipose tissue development and insulin resistance in mice. J Thromb Haemost 3: 1174-1179.

24. Weisberg AD, Albornoz F, Griffin JP, Crandall DL, Elokdah H, et al. (2005) Pharmacological inhibition and genetic deficiency of plasminogen activator inhibitor-1 attenuates angiotensin II/salt-induced aortic remodeling. Arterioscler Thromb Vasc Biol 25: 365-371.

25. Gorlatova NV, Cale JM, Elokdah H, Li D, Fan K, et al. (2007) Mechanism of inactivation of plasminogen activator inhibitor- 1 by a small molecule inhibitor. $J$ Biol Chem 282: 9288-9296.

26. Elokdah H, Abou-Gharbia M, Hennan JK, McFarlane G, Mugford CP, et al (2004) Tiplaxtinin, a novel, orally efficacious inhibitor of plasminogen activato inhibitor-1: design, synthesis, and preclinical characterization. Journal of Medicinal Chemistry 47: 3491-3494.

27. Bajou K, Peng H, Laug WE, Maillard C, Noel A, et al. (2008) Plasminogen activator inhibitor-1 protects endothelial cells from FasL-mediated apoptosis. Cancer Cell14: 324-334.

28. Fang H, Placencio VR, DeClerck YA (2012) Protumorigenic activity of plasminogen activator inhibitor-1 through an antiapoptotic function. Journal of the National Cancer Institute 104: 1470-1484.

29. Rossignol P, Anglès-Cano E, Lijnen HR (2006) Plasminogen activator inhibitor-1 impairs plasminogen activation-mediated vascular smooth muscle cell apoptosis. Thromb Haemost 96: 665-670.

30. Rossignol P, Luttun A, Martin-Ventura JL, Lupu F, Carmeliet P, et al. (2006 Plasminogen activation: a mediator of vascular smooth muscle cell apoptosis in atherosclerotic plaques. J Thromb Haemost 4: 664-670

31. Horowitz JC, Rogers DS, Simon RH, Sisson TH, Thannickal VJ (2008) Plasminogen activation induced pericellularfibronectin proteolysis promotes fibroblast apoptosis. Am J Respir Cell Mol Biol 38: 78-87. 